Reviews

\title{
Why Do Expressive Campaigns Succeed and Fail? A Review Essay on Eco-Wars: Political Campaigns and Social Movements, by Ronald T. Libby. New York: Columbia University Press (1998), 254 pp.
}

\author{
Reviewed by Archon Fung, Kennedy School of Government, Harvard University, \\ Cambridge MA.
}

The wars that social movements wage are composed of many kinds of battles--guerilla street protests, psychological struggles for the hearts and minds of would-be recruits and sympathizers in coffee-klatches and mass media, and pitched confrontations in formal political arenas. In his Eco-Wars: Political Campaigns and Social Movements, Ronald Libby examines five important cases that fall into the last category: an effort to ban agricultural biotechnology, animal rights in Massachusetts, the so-called "Big-Green" omnibus environmental initiative in California, a second-hand smoke contest also in California, and a national effort to reform the Endangered Species Act. He calls these confrontations "expressive political campaigns" because they lie in the less charted regions between social movement organizing and interest group activity. In their post-material purpose and grassroots constituencies, they resemble social movements. In their battlegrounds of ballot measures, administrative decisions, and law-making and their techniques of professional public relations, expressive political campaigns are more like interest group skirmishes.

The book should be read carefully by those interested in campaigns, social movements, interest groups, and environmental politics, for it offers rich and detailed case studies of major contests. Based upon this case material, Libby contends compellingly that money isn't everything in politics and legislation, and in particular that the interest group sphere, conventionally dominated by economic Goliaths, can sometimes be penetrated by environmental and grassroots Davids. A careful reading of his cases sheds light not only on the sources of success in these campaigns, but critically their sources of failure.

This positive case for the importance of social movement involvement in political campaigns must be tempered somewhat by Libby's result that only one of the five campaigns is a clear victory: the battle between tobacco corporations and anti-smoking activists over second-hand smoke ordinances in California. The sources of victory in this case, moreover, seem to be quite idiosyncratic, and so its possibilities for generalization are quite limited. By the early 1990s, local governments all over California had passed ordinances to restrict smoking in public places to prevent alleged harms from second-hand smoke inhalation. In response, tobacco companies concocted a statewide initiative, Proposition 188, that would supercede local ordinances by establishing uniform weaker anti-smoking provisions throughout the state. Since they suffered from public distrust, Philip-Morris and other backers framed Proposition 188 as an anti-smoking ordinance and conducted a stealth campaign in which they concealed their sponsorship. Once anti-smoking activists publicized industry sponsorship, public opinion turned decisively against the initiative. It was defeated in 1994 by a vote of 42 percent against and 29 percent in favor. In the other four cases (and in political campaigns generally), activists did not enjoy a high ground in which industry occupied a fragile and deliberatively unstable position.

Libby attributes the success of the anti-smoking activists to three factors: the presence of a mobilization infrastructure of activists in civil society and government, their ability to reframe Proposition 188 as an pro-smoking ordinance rather than an anti-smoking effort, and the absence of free-rider problems because social movement groups were unified in support of this cause. These generic explanations, however, miss crucial features of the initial positions that anti-smoking activists and tobacco companies occupied in this campaign. As evidenced by their campaign strategy, industry was on the defensive throughout, and that opening advantage was as crucial as any other factor in the determining the ultimate outcome.

In this and his four other cases, Libby relies heavily on mechanisms such as framing, free-rider-problems, and the formation of alliances and opponents as the conceptual apparatus with which to understand the success and failure of social mobilization and political struggle. While these explanations no doubt figure into each, the highlevel of resolution of his cases reveals that more specific and contextual factors may have been more decisive. Unfortunately, Libby fails to incorporate his substantial case-level insights into his more general explanatory and theoretical understanding.

For example, the institutional particulars of the political spaces in which these campaigns were waged seemed crucial to their dynamics and outcome. Three of them -- the animal rights struggle in Massachusetts, the California "Big Green," and second hand smoke -- took the form of popular ballot initiatives. This institutional space lends itself to particular techniques of professional public relations, media blitzes, and grassroots face-to-face 
Reviews

appeals in ways that other political arenas do not. The bias inherent in this form will reward the capacities of some political actors and disadvantage others. So, for example, the decisive factor in the case of the Massachusetts animal rights initiative turned out to be small farmers who appealed directly to voters at transit stops, shopping centers, and automobile stops (pp. 81-84) against the measure. In the "Big Green" initiative, capricious events outside the control of political actors seemed decisive. Libby tells us that the Gulf War and fears of escalating gas prices increased public concern with economic issues at the expense of the environment. Since opponents of Big Green had based their arguments on economic costs, they benefited from this sudden exogenous shift in public perception.

Similarly, other arenas lend themselves to different kinds of capacities and biases. So, for example, the campaign against the industrial use of bovine somatotropin, or bovine growth hormone (BST/BGH), depended upon the administrative decision of the Food and Drug Administration. This arena, intended to be the purview of experts and neutral science, is of course not at all insulated from direct political appeals, but neither is it an open contest like a ballot initiative. Here, success or victory is likely to rely the ability of insurgents to challenge professional analyses, conceptions of risk, and standards of proof (Brown 1992, Epstein 1996, Jasanoff 1999).

The fifth case details grassroots attempts to replace the Endangered Species Act with decentralized and largely privatized regulation under Congressional reform legislation. Here, too, the dynamics and sources of influence are dependent on institutional particulars and differ from either ballot initiatives or agency decisions. In this instance, the reform movement's defeat arose from the prior strength of elite and popular sentiment (again, initial conditions) in favor of environmental protection generally, and Speaker of the House Newt Gingrich's recognition of that power and his consequent reluctance to push reform legislation.

Libby also downplays the importance of money in these campaigns and argues that expressive groups can deploy non-monetary resources to occasionally prevail. The case evidence only partially bears out this conclusion. Expressive groups still seem to require substantial, albeit perhaps not equal, resources to mount respectable challenges to well-resourced factions. Both sides in the "Big Green" battle, for example, committed millions to its cause. Though tobacco interests out-spent anti-smoking activists in that case, crucial funding on the order of $\$ 4$ million from foundations fueled the media strategy that exposed the behind-the-scenes support of tobacco companies.

Beyond extending categories of explanation, the book might have used the case materials to explore two quite broad and important sets of questions. Perhaps Libby, or another scholar inspired by his work, will pursue these in subsequent research. The first concerns the implications of these campaigns for the social movements that gave birth to them. Though wars are not won by losing battles, neither is it necessary to prevail in every battle to win the war. In particular, students of social movements will want to know how these expressive political campaigns bolster or weaken the larger social movements of which they are part. For example, students of the women's movement have debated whether the historic Roe v. Wade decision counter-intuitively weakened the pro-choice movement by removing its mobilization incentives (Tushnet 1989, Fung 1993). Similarly, did the need to exaggerate claims and use of professional public relations techniques weaken the long-term viability of grassroots movements in the course of these campaigns? Conversely, did face-to-face appeals of small farmers and other groups enhance the capacities of these groups for other activities?

Second, what are the lessons of these campaigns for innovative environmental strategies that extend beyond traditional legislation and rule-making (Sabel, Fung, and Karkkainen 2000)? Interestingly, Libby argues that two of his cases exhibited partial success. The campaign against BST/BGH did not yield an FDA ban, but the agency did permit voluntary labeling of dairy products free from BST/BGH. This opened the way for environmentalists to press their case to the public at large and attempt to change the behavior of consumers and retail grocers. Similarly, the grassroots campaign to weaken the Endangered Species Act was a victory in part because the Department of the Interior shifted from command-and-control implementation to more decentralized and negotiated methods under the aegis of Habitat Conservation Planning (HCP). Amendments to endangered species legislation allow landowners to obtain waivers by producing local plans for habitat management and species protection. While many environmentalists criticize this provision for eroding protection, it also creates opportunities for environmentalists to engage with those who seek permits to design effective management and species recovery programs (Thomas 2000). In order to utilize opportunities created by these two partial successes, social movements and interest groups must develop strategies, tactics, and capacities that reach beyond conventional campaigning at the state and national levels to dispersed constituencies of consumers and citizens or decentralized and particularistic challenges of ecosystem management.

Many of the battles of the eco-wars of the twenty-first century will be fought in these low-intensity political arenas (Weber 1999). Scholars of environmental politics should turn some of their attention to understanding the dynamics of that terrain, and students of social movements should ask how the expressive political groups that 
Reviews

Libby chronicles are rearming and reconfiguring themselves for these new dimensions of engagement.

References Cited:

Brown, Phil.

1992. Popular Epidemiology and Toxic Waste Contamination: Lay and Professional Ways of Knowing.

Journal of Health and Social Behavior 33:267-81.

Epstein, Steven.

1996. Impure Science: AIDS, Activism, and the Politics of Science. Berkeley: University of California Press.

Fung, Archon.

1993. Making Rights Real: Roe's Impact on Abortion Access. Politics and Society 21:465-504.

Jasanoff, Sheila.

1999. Technological Risk and Cultures of Rationality, unpublished ms.

Sabel, Charles, Archon Fung, and Bradley Karrkainen.

2000. Beyond Backyard Environmentalism. Boston: Beacon Press.

Thomas, Craig

(forthcoming, 2001). Habitat Conservation Planning: Certainly Empowered, Somewhat Deliberative,

Questionably Democratic. Politics and Society, vol. 29.

Tushnet, Mark.

1989. Rights: An Informal Essay in Political Theory. Politics and Society 17:403-452.

Weber, Edward P.

1999. The Question of Accountability in Historical Perspective: From Jacksonian to Contemporary

Grassroots Ecosystem Management, Administration and Society 41:451-494.

\section{Democratic Commitments: Legislatures and International Cooperation, By Lisa L. Martin, Princeton, N.J.: Princeton University Press (2000), viii, 225 pp.}

\section{Reviewed by: Leslie R. Alm and Ross E. Burkhart, Department of Political Science, Boise State University}

In Democratic Commitments, Lisa Martin challenges the long-held, mainly realist assumption that international relations do not operate according to the same laws of political behavior as do domestic politics. She does this by exploring the general problem of international cooperation and how this cooperation is related to the demand for credibility. More specifically, Martin approaches the problem of international credibility by examining the domestic source of commitments through the role of national legislatures in established democracies. She finds that the degree of legislative influence on international cooperation far exceeds common estimates. Further, she finds this true in both presidential and parliamentary systems. In the end, Martin concludes that institutionalized legislative participation in international cooperation not only enhances the credibility of states' commitments, it leads to more stable and deeper patterns of international cooperation. Martin's contribution, thus, is at two levels: that of the nature of international cooperation, and that of the performance of democratic countries in foreign policy.

Martin uses her first two chapters to establish her framework of study and to provide readers with her research conclusions. In doing so, she identifies two central research questions: how to explain variation in legislative influence on foreign policy, and how legislative participation affects stable democracies' ability to make commitments to other states. In search of finding answers to these questions, Martin suggests that rather than viewing the executive-legislative relationship as a zero-sum game where one side must lose, we are much better off by thinking of executive-legislative relations as an exchange relationship where competition coexists with the pursuit of mutually beneficial deals. This is a theme (position) that Martin returns to again and again throughout her work, lending a neoliberal perspective to it. Furthermore, Martin allows that once we accept this view of a mutually beneficial exchange relationship between the executive and legislative branches of government, the potential of 